\title{
Climate Change and its Increasing Impacts in Nepal
}

\author{
Madhav Karki ${ }^{1}$, Pradip Mool and Arun Shrestha
}

\begin{abstract}
There is a general agreement that Climate Change impacting Nepal rather disproportionately compared to its size and its own meagre contribution of the green house gases. However, given its location between two rapidly growing economies of India and China, Nepal cannot escape the rapidly increasing influence of climate and global changes. The rapidly retreating glaciers (average retreat of more than $30 \mathrm{~m} /$ year), rapid rise in temperature $\left(>0.06^{\circ} \mathrm{C}\right)$, erratic rainfalls and increase in frequency of extreme events such as floods and drought like situation are some of the effects Nepal is facing during the last few years. Most of the big rivers of Nepal are glacier-fed and its main resources of water and hydroelectricity will be seriously affected due to the ongoing changes in glacier reserves, snowfall and natural hazards. Nepal has to prepare itself to try and mitigate these effects if possible and if not adapt to them to reduce their impacts on our lives and livelihoods. Nepal is largely a mountainous country and current indications are that the mountain regions are more vulnerable due to increased warming trends as well as extreme changes in altitude over small distances. These alarming trends not only make Nepal's major sectors of economy such as agriculture, tourism and energy more vulnerable but also endanger the health, safety and wellbeing of Nepali people. Biodiversity - the other important resources of Nepal is also being affected as invasive species will spread fast and useful medicinal, food and nutrition related plants may disappear. Climate change is becoming already dangerous to our survival and we have to do everything possible to prevent it being catastrophic to us. The globally accepted strategy to contain disastrous climate change impacts is Adaptation and Mitigation. For a least developed country such as Nepal, adaptation should be the priority. Nepal is currently preparing National Action Plan on Adaptation (NAPA) which should be made as comprehensive and topical as possible. Well coordinated, quick and serious implementation of NAPA will be extremely important to mitigate and adapt to the growing impacts of climate change in Nepal. Nepal's central location in the Himalaya portends the fact that it is the prime target country of climate change impacts and calls for it to play a leadership role at least in showing political will and playing a responsible role in global events such as the COP-15 at Copenhagen.
\end{abstract}

हरित गृह ग्यास उत्शर्जनको अति न्यून हिस्सा नेपालले ओगटे पनि यसको आकारको अनुपातमा जलवायु परिवर्तनले नेपाललाई असमान हिसाबले असर पारिरहेको छ। दुई उदाउँदा महाशक्ति, भारत र चिनको विचमा अवस्थित हुनालेपनि नेपाल जलवायु परिवर्तनको विश्वव्यापी असरबाट अछुतो रहन सक्दैन। हिमनदीहरुको तिब्र विलय (औसत ३० मी भन्दा बढि), तिव्र तापमान वृद्धि ( $0.0 ६$ डि. से. भन्दा बढि ), अस्वभाविक वर्षा, बढ़दो बाढि पहिरो अनि सुख्खा जस्ता घटनाहरु जलवायु परिवर्तनको असरका केही नमुना हन्। यसले नेपाली अर्थ व्यवस्थाका प्रमुख खस्बा कृषी, वन, पर्यटन र उर्जामात्र नभई स्वास्थ्य, सुरक्षा, र जीवनशैलीलाईनै असर पार्ने देखिन्छ। यसका असरहरुसँग लढ़न नेपालले पूर्व तयारी गर्नुको साथै अनुकुलनका उपायहरु अवलम्बन गर्नु पई्छ। नेपालले बनाउन लागोको अनुकुलनको नीति वृहद, विषयगत, समकदारीयुक्त र छोटो समयमा कार्यान्वयन गर्न सकिने हुनुपई ।

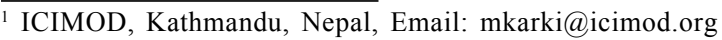




\section{Basic facts}

Climate change is fast becoming a major issue of concern to both Nepal and Nepalese people. If the average annual temperatures increases as per the current annual rate of 0.06 OC all aspects of our life and livelihood will be affected. Climate change is already threatening Nepal's food security, human habitats, water resources and tourism sectors seriously. Nepal and the entire greater Himalaya region will be facing multiple challenges due to climate change. Mountain landscape including our Himalayan glaciers - the central part of the water towers of South Asia - agriculture, health, forests and pastures are already showing indications of climate change impacts. If we add increasing fuel and food crisis to the climate change related problems, Nepal's national agenda such as poverty reduction, water management, and human safety and security will face unimaginable challenges and Nepal will further get exposed to increasing natural and human made disasters.

The mountain regions are more vulnerable because it has been seen that both the warming trends as well as the impacts are magnified due to the extreme changes in altitude over small distances. Majority of Nepalese people's source of livelihood is agriculture which relies strongly on the monsoon systems and indications are strong that the monsoon pattern especially rainfall timing, frequency, duration and intensity all may be altered due to climate change. Traditionally, people have been adapting to small changes in weather patterns and climatic variations but as these changes intensify peoples' ability to adapt will be challenged and they simply may resort to coping.

\section{Climate change indications in the Hindu Kush-Himalayas}

The recorded rates of warming in the Himalaya are significantly higher than the global average. Within the region, the rates in the western Himalayas, eastern Himalayas, and the plains of the Ganges basin over the last 25 years are lower $\left(0.01-0.03^{\circ} \mathrm{C}\right.$ per yr), and those for the Nepal Himalayas and the Tibetan Plateau (based on limited station data), appear to be considerably higher $\left(0.04\right.$ to $0.09^{\circ} \mathrm{C}$ per yr and $0.03-0.07^{\circ} \mathrm{C}$ per yr respectively). The measurements in Nepal and Tibet also indicate that warming is occurring at much higher rates in the high altitude regions than in the low altitude areas; the vast low elevation areas of India do not show any significant signs of warming.

The monsoon rainfall in Nepal like in other South Asian country is to a large scale correlated with regional climatologically phenomenon but as yet the total rainfall has not shown any decreasing or increasing trends due to climate change. However, there are signs of changes in the dates of onset and retreat of the monsoon as well as the number and frequency of extreme precipitation events, although more analysis is still needed to confirm this. For the past two years, we have noticed the intermittent drought like situation during the monsoon season. 
Analysis and predictions of climate change in Nepal are still based on literature review and some scattered information. There is still no plan in place to collect long-term high quality data to carry out reliable analysis and predictions. The topography is also very challenging in case of Nepal; the extreme changes in height over short distances (from about 65 meter to $8848 \mathrm{~m}$ within $120 \mathrm{~km}$ span) can lead to extreme changes in rainfall amounts and other climate-related events over a small area. This extreme topography presents a challenge both for measuring actual rainfall and for assessing other climate factors, especially as weather monitoring stations are few and far between. Similarly, it is still difficult to develop models that take into account the influence of the local topography on the climate. Some researchers are projecting that all areas of South Asia will warm by at least $1^{\circ} \mathrm{C}$ by the end of the century; in the Punjab area, a large part of Afghanistan, Badakshan, the western Nepal Himalayas, Himachal Pradesh, and the northern Tibetan Plateau, warming could be as high as $3.5-4^{\circ} \mathrm{C}$. The rate of warming is likely to increase with increasing altitude, at least in Bhutan, Nepal, and Himachal Pradesh.

Himalayan mountains thus also play a special role in understanding climate change. One of them is through study of glaciers. As the glaciers are receding, there will be changes in the disaster risk to the people's lives and livelihoods in the region. Climate change is speeding up glacier melting, affecting the alpine pastures and the animals like Yak who are depending on them, and causing tree lines and other vegetation to advance upslope and decreasing summer or dry season water flows from glacier-fed rivers. The increase in glacier melting and resultant GLOF has already caused flash floods in Khumbu region (Figure 1).

\section{Implications of climate change}

\section{Less water}

One of the most visible impacts of climate change in the Himalayan region is the retreat of the glaciers, many at higher rates than seen in other mountain ranges. The permanent snowline

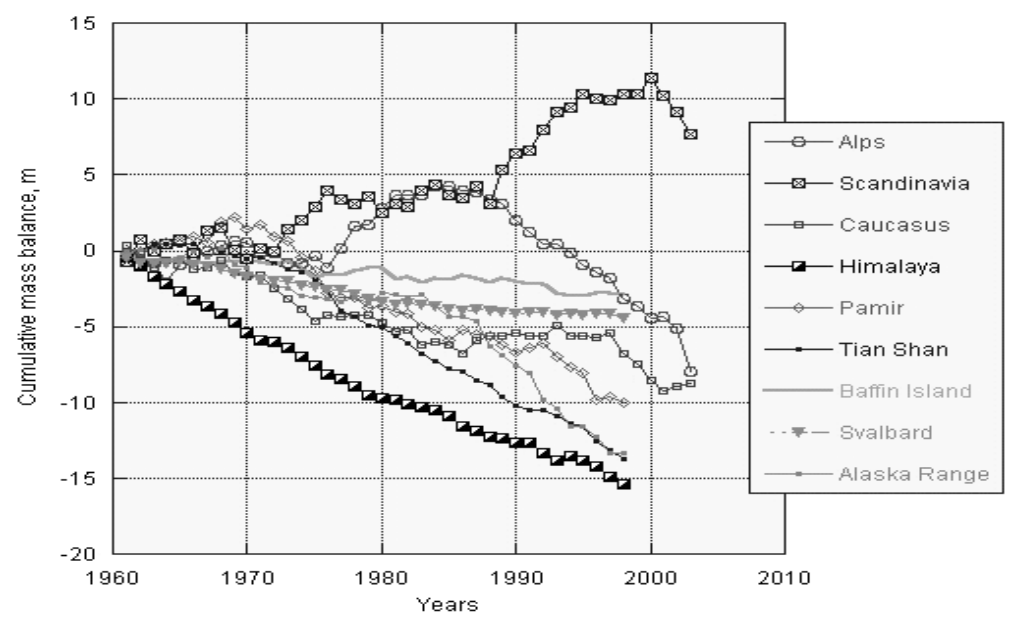

Figure 1: Rate of deglaciation in different mountain ranges has moved significantly higher, although the observations are too few to be able to quantify the actual loss of snow cover in the region. But one thing is sure; continued deglaciation could have a profound impact on the water in the ten large river basins originating in the $\mathrm{HKH}$ region. River discharges 
are likely to increase for some time due to accelerated melting, but the flow is then likely to be lower as the storage capacity of the glaciers will go down. The effects are likely to be felt most severely in the arid parts of the region which are already very dry. The Figure 1 below indicates the highest rate of deglaciation in the Himalaya.

ICIMOD has studied the impact of projected climate change on the hydrological regime of some river basins, and shown a clear difference between the basins dominated by summer monsoon and those dominated by winter precipitation. These studies did not indicate that there would be a catastrophic scarcity of water, as commonly predicted, although uncertainties remain due to the coarseness of the models and lack of data for validation and calibration.

\section{Glacial lake outburst floods}

Glacial lakes have formed in many places in the area left at the foot of retreating valley glaciers. An inventory compiled by ICIMOD identified 8790 glacial lakes within selected
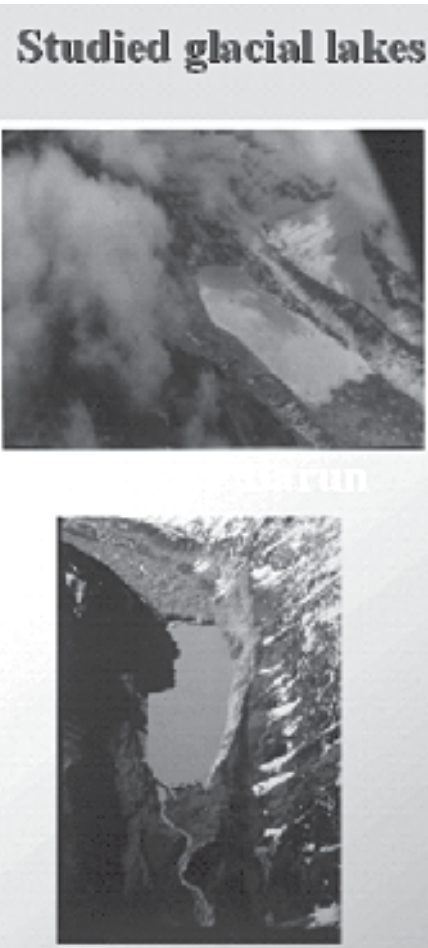

Thulat반

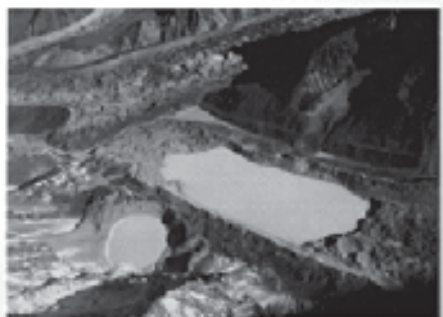

$\operatorname{Imin}$

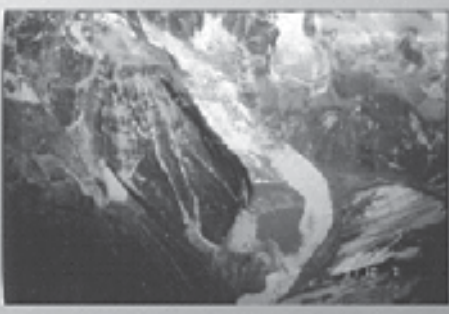

Dig Tsho

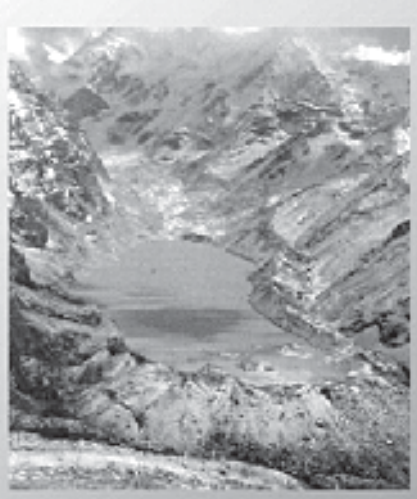

Tsho Rolpa

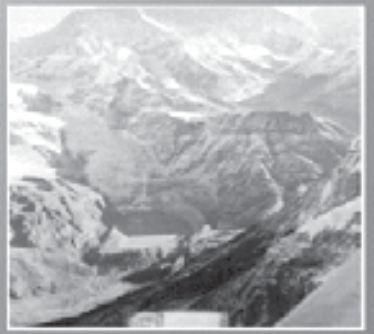

Tam Pokhari

Figure 2: Glacial lakes formed in different parts in Eastern Himalaya

parts of the Hindu Kush-Himalayas. Some 204 of the glacial lakes were considered to be potentially dangerous, that is liable to burst out leading to a glacial lake outburst flood (GLOF). There have been at least 35 GLOF events in Bhutan, China and Nepal during the $20^{\text {th }}$ century. Figure 2 above shows the glacial lakes formed in different parts in Eastern Himalaya. 


\section{Floods and drought}

Floods and droughts are likely to increase as a result of a number of factors. An increase in seasonal change is predicted with more precipitation during the wet season leading to increased flood risk, and potentially drier dry seasons with increased risk for drought. Changes in the monsoon regime might lead to an overall increase in precipitation in some areas, and a decrease in others. There are also likely to be more flash floods resulting from increased numbers and magnitude of extreme precipitation events, and there may be greater direct runoff and less delayed runoff as less precipitation falls as snow.

\section{Ecosystem services}

Climate change is already affecting ecosystem services by affecting forest type and area, primary productivity, species populations and migration, the occurrence of pests and disease, and forest regeneration. The increase in greenhouse gases is also affecting species composition and changing the ecosystem structure, which in turn affects ecosystem function. The interaction between elevated $\mathrm{CO}_{2}$ and climate change plays an important role in the overall response of net primary productivity. Climate change will have a profound effect on the future distribution, productivity, and ecological health of forests. There could be a significant reduction in alpine and cryospheric ecosystems and their services. A major expansion of the tropical zones would cover most of the middle mountains and inner valleys of the region, whereby the quality and quantity of ecosystem services are likely to change dramatically for the worse.

\section{People's well-being}

Climate change can affect people's wellbeing in a variety of ways. It is likely to exacerbate the existing food insecurity and malnutrition. Vector-borne diseases such as malaria and dengue fever are likely to move to higher altitudes. Water-borne diseases are also likely to increase with the increasing water stress accompanied by the lack of safe drinking water and basic sanitation in the region. Deaths and morbidity associated with extreme and erratic weather are also likely to increase. Climate change will have differentiated impacts which could be more severe for women, and poor and marginalised groups.

\section{Contribution of the HKH countries to global greenhouse gas emissions}

Six countries in the Hindu Kush-Himalayan region have prepared greenhouse gas inventories (Bangladesh, Bhutan, China, India, Nepal, and Pakistan). Together these countries emit approximately $17 \%$ of the total global greenhouse gas emissions which is low compared with their area and population. The average emissions from the HKH part of these countries is likely to be much lower than the country average as the mountain regions are sparsely populated and much less industrialised. There is a considerable disparity between the countries with China emitting $12 \%$ of the global total, India $4 \%$, and Bhutan acting as a net sink. The 
emissions from these countries are expected to increase further with future economic growth (UNFCC). The relative values are approximate as the inventories refer to different years.

\section{Climate change impact on the mountains}

Climate crisis is, therefore real and requires urgent attention through joint, concerted and immediate national and cross border efforts. Mountain environments, worldwide, are likely to be some of the most severely impacted ecosystems in the World from future climate change. The Himalayan alpine zone is particularly sensitive to changes in temperature and precipitation. Mountain areas are threatened by loss of natural habitat for our rich flora and fauna. Our mountain ecosystems and plants and animal species therein are predicted to slowly migrate and shift their distribution northward or upward in response to warming temperatures. Scientists are already noticing shifts in vegetation boundaries from various alpine areas in our mountain ecosystems. Mountains are naturally and physically vulnerable areas. Climate change, now recognized as the most critical global challenges of our times, has the potentials to convert these vulnerabilities and potential natural hazards into severe natural disasters like floods, crop failures and outbreak of pandemic diseases as has been already demonstrated in recent years: accelerated glacier melting, increased erosion of our thin soil cover and nutrients, slope instability, flash floods etc. In the long run, reduced water availability for drinking, irrigation and hydropower, species extinction and eventual extinction and the spread of vector-borne diseases are some of the effects, we are facing. Himalaya is a rich biodiversity hotspot with a number of endemic species of flora and fauna upon which livelihoods of millions of poor and vulnerable population depend. Climate change may affect the critical ecosystems services and environmental flow with potential adverse impacts on the livelihoods and well being of millions of people living not only in the core areas of Eastern Himalayan slopes but also in the downstream ecosystems.

\section{The role of adaptation in reducing climate change impacts}

The $4^{\text {th }}$ report of the International Panel on Climate Change (IPCC) has characterised the $\mathrm{HKH}$ region as a data deficit or white spot due to its poor availability of data and information, lack of regional analysis, and poor information base on hydrological processes and meteorological systems. Based on the available trends and projections especially the increase in temperature, there is a general agreement on the possibility of serious impacts of climate change on Himalayan environment and water resources including the critical sources of peoples' livelihood. We in ICIMOD feel that academics, researchers, students, development workers, concerned citizens, national and regional policy makers and most importantly opinion makers on mountain development including ecosystem services including community leaders can raise public awareness and policy debate and identify gaps in information and knowledge so that we can develop the required information, knowledge and good practices and support the government run programs to mitigate and adapt to the impact of climate 
change to the Nepalese people. The aim is to help our vulnerable communities like those who live in Everest region to have suitable coping strategies and become more resilient to climate change effects.

Climate change is becoming already dangerous to our survival and we have to do everything possible to prevent its catastrophic impacts. The globally accepted strategy to contain disastrous climate change impacts is Adaptation and Mitigation. For a least developed country such as Nepal, mitigation is not a priority. As per UNFCC agreement, Nepal is required to prepare National Action Plan on Adaptation or NAPA and the ongoing preparation and implementation of a comprehensive NAPA will be a good way forward for Nepal. Nepal's location in the central Himalaya which forms the catchments of the vast agriculturally and industrially important Indo-Gangetic plains make it both vulnerable and suitable to play a significant role in addressing the issues of climate change for the entire Indian sub continent. In the upcoming COP-15 in Copenhagen, Nepal can play a major role demonstrating its resolve to address climate change issues for regional and global benefits. Nepal's successful community forestry can provide opportunity for voluntary carbon finance through instruments such as REDD.

\section{ICIMOD's work in climate change}

The International Centre for Integrated Mountain Development, ICIMOD, is a regional knowledge development and learning centre serving the eight regional member countries of the Hindu Kush-Himalayas - Afghanistan, Bangladesh, Bhutan, China, India, Myanmar, Nepal, and Pakistan - and based in Kathmandu, Nepal. Globalization and climate change have an increasing influence on the stability of fragile mountain ecosystems and the livelihoods of mountain people. ICIMOD aims to assist mountain people to understand these changes, adapt to them, and make the most of new opportunities, while addressing upstreamdownstream issues. We support regional transboundaryprogrammes through partnership with regional partner institutions, facilitate the exchange of experience, and serve as a regional knowledge hub.

ICIMOD carries out a wide range of activities related to climate change. ICIMOD is working towards generating regional baseline data, particularly on cryosphere and climate change, and developing mechanisms for sharing of data and information. The HKH region is considered as lacking the data needed to assess climate change and its impacts accurately. The problems relate both to lack of data and analyses, and to a lack of appropriate mechanisms for data and information sharing and dissemination (including, for example, lack of long-term data sets and problems with data quality). ICIMOD's focus is on developing baseline data and information and reducing gaps and uncertainties. Recently, ICIMOD has developed the concept of using a transect approach to focus efforts for long-term monitoring of climate change impacts. 


\section{Conclusion}

We feel that Nepal should plan to have economic development and environment conservation program that aims for: a) Low carbon economy, b) efficient use of natural especially water and forest resources through higher resilience and adaptation methods, and c) regional cooperation to promote equity and fairness through instruments such as Payment for Ecosystem Services (PES). In terms of implementation of adaptation plans, we should have two pronged development strategy: a) resolving of conflicting demands of conservation and development and b) matching interests of poor with interests of environment. 